\title{
Trend of Regulatory T-Cells in the Pathogenesis of Leishmania Infection
}

\author{
Dayakar Alti*1, Suresh Kumar Kalangi ${ }^{2}$ \\ ${ }^{1}$ Sathivda, Nellimarla, Vizianagaram, Andhra Pradesh, India \\ ${ }^{2}$ Indrashil University, Department of Biosciences, India
}

Received: 制: October 23, 2018; Published: 制: November 06, 2018

*Corresponding author: Dayakar Alti, Sathivda, Nellimarla, Vizianagaram, Andhra Pradesh India, Pin: 535218, India

\begin{abstract}
Leishmaniasis is a global health issue, every year killing thousands of people around the world, majorly from tropical and subtropical countries. It is prevalent mostly in the poorest population suffering from malnutrition and immune dysfunction. Though macrophages have enrolled in the first-line of defence, Leishmania parasite evades macrophage antimicrobial machinery to establish the infection. Before the infection become chronic, T-cell (Th1 subset) plays a crucial role in the complete elimination of the parasite by means of inflammatory response, with appropriate chemotherapy. If it fails, infection become chronic and persists for several years; this situation lead by initially Th2 cells followed by and T-regulatory cells (T-regs). During control of excessive inflammation, T-regs may divert the host immune response in favour of the parasite persistence in lymphoid tissues. In this report, I have presented the trend of regulatory T-cells in the establishment of chronic infection that develops symptomatic disease.
\end{abstract}

Abbreviations: VL: Visceral Leishmaniasis; PKDL: Post-Kala-Azar Dermal Leishmaniasis; MCL: Mucocutaneous Leishmaniasis; T-reg: Regulatory T-Cells; CL: Cutaneous Leishmaniasis; DCs: Dendritic Cells

\section{Introduction}

Leishmania infection in humans is usually sub-clinical, where the parasite persists for the life-time of host. Low grade infection is typically controlled by the cell-mediated immune response (selfcure) or by successful chemotherapy [1]. If the person is immunocompromised, the infection leads to the development of symptomatic clinical disease; including the reactivation of kala-azar/visceral leishmaniasis (VL) as found in HIV patients [2], development of post-kala-azar dermal leishmaniasis (PKDL) after apparent cure of VL [3], reactivation of localized dormant skin lesions, and the development of destructive mucocutaneous leishmaniasis (MCL) several months after healing of localized skin lesions in normal healthy individuals $[4,5]$. Generally, immunological homeostasis of a host is maintained by specialized subsets of T-lymphocytes called regulatory T-cells (T-reg). Till date, various types of T-regs have been described in human and mice [6-10].

The naturally occurring T-regs (CD4+CD25+Foxp3+) resides in the thymus and peripheral blood [11-16], which constitutes around $5-10 \%$ of peripheral CD4+ T-cells and have crucial role in the control of autoimmunity $[17,18]$ and maintenance of selftolerance. This statement was validated for the first time by the observation of developing fatal autoimmune disorders in mice with neonatal thymectomy; however, transfer of CD4+CD25+ T-cells purified from normal mice prevented these outcomes $[17,19,20]$. The transcription factor Foxp3 encodes for a forkhead/wingedhelix transcription repressor named Scurfin, whose expression is mainly restricted to CD25+CD4+ T-reg cells and regulates their development and function [21,22]. FOXP3 mutations in humans cause immune dysregulation, polyendocrinopathy, enteropathy, and $\mathrm{X}$-linked syndrome, together called as IPEX, which is characterized by high incidence of autoimmune diseases including type-1 diabetes, thyroiditis, inflammatory bowel disease, and allergic disease such as atopic dermatitis and food allergy [23-28].

\section{T-regs in Chronic Leishmania Infection}

T-regs may be a part of misdirected immune responses [2931] and play a significant role in the reactivation of dormant infection, studied in pathogenesis of Leishmania infection [32-35]. Persistence of Leishmania in the experimental skin model found to be controlled by CD4+CD25+ T-reg cells [36]. Moreover, in intradermal low dose of L. major cutaneous infection model, T-reg cells are essential for maintenance and development of persistent skin lesions. T-reg cells rapidly accumulate at the site of L. major infection, suppressing the ability of the immune response which involve in the complete elimination of the parasite. Establishment of chronic infection and the maintenance of a constant number of parasites at 
the site of infection depend on a tight equilibrium between effector lymphocytes and T-reg cells. More over depletion of CD25+ cells at the time of secondary challenge prevented disease reactivation at the primary site, while strengthening the expression of immunity in the challenged site $[37,38]$. Finally, the transfer of T-reg cells purified from chronically infected mice into non-symptomatic infected mice was sufficient to trigger the disease reactivation and prevent the expression of effector memory response.

The equilibrium between T-regs and effector lymphocytes, which could be distributed in the case of super-infection, controlled the efficiency of recall immune response and disease reactivation [38]. However, in the case of human VL no evidence has been found to support a role for CD4+CD25+ cell-mediated immune suppression [39]. In humans, a subset of T-cells that produce both IFN- $\gamma$ and IL-10- was found to be significantly higher in Leishmania antigen activated PBMC cultures derived from individuals with a past history of VL [40]. IL-10 was produced by innate cells as well as CD4+CD25+Foxp3+ and CD4+CD25-Foxp3- T-cells in the chronic lesion of cutaneous leishmaniasis (CL). Nonetheless, only IL-10 production by antigen-specific CD4+CD25-Foxp3- T-cells, the majority of which also produced IFN- $\gamma$, was necessary for suppression of acquired immunity in Rag-/-reconstituted mice [41]. In experimental models, absence or inhibition of T-regs or IL10 promotes complete clearance of parasite, whereas depletion of effector cells or cytokines (e.g. IFN- $\gamma$, IL-12) promotes reactivation $[1,42,43]$.

During the chronic phase of the infection a high number of both IFN- $\gamma$ producing effector lymphocytes (CD4+CD25- T-cells) and IL-10 producing T-reg cells (CD4+CD25+ T-cells) accumulate at the site of infection. In human VL, elevated level of IFN- $\gamma$ mRNA in lymphoid organs is correlated by the high expression of IL-10 [4446], where the predominant source of IL-10 is Foxp3-CD25-CD3+ cells [39]. In accordance to this, a subset of regulatory dendritic cells (DCs) in the L. donovani infected spleen produce IL-10 that induce the expansion of IL-10-producing regulatory T-cells and inhibit the antimicrobial potential (reactive oxygen and nitrogen intermediates production) of macrophages and other phagocytic cells. IL-27 producing regulatory DCs or macrophages and IL-21 producing T-cells together drives the differentiation of Th1 cells into T-regs and also inhibits the development Th17 phenotype. IL10 produced by T-regs suppresses antigen presentation, mediates T-cell dysfunction, and inhibits IFN- $\gamma$ producing CD4+ T-cells [47]. Finally, the role T-regs was elucidated in modulating both Th1 and Th2 activity during murine L. major infection [32,35,36].

\section{Conclusion}

In conclusion, acquiring better knowledge about Leishmania species-specific T-reg cell phenotypes, function, and their network of interaction and regulation with other subset of T-cells could help in finding a novel immunological target for the cure of leishmaniasis.

\section{References}

1. Stenger S, Donhauser N, Thuring H, Rollinghoff M, Bogdan C (1996) Reactivation of latent leishmaniasis by inhibition of inducible nitric oxide synthase. J Exp Med 183(4): 1501-1514.
2. Alvar J, Canavate C, Gutierrez-Solar B, Jimenez M, Laguna F, et al. (1997) Leishmania and human immunodeficiency virus coinfection: the first 10 years. Clin Microbiol Rev 10(2): 298-319.

3. El Hassan AM, Ghalib HW, Zijlstra EE, Eltoum IA, Satti M, et al. (1992) Post kala-azar dermal leishmaniasis in the Sudan: clinical features, pathology and treatment. Trans R Soc Trop Med Hyg 86(3): 245-248.

4. Saravia NG, Holguin AF, McMahon-Pratt D, D Alessandro A (1985) Mucocutaneous leishmaniasis in Colombia: Leishmania braziliensis subspecies diversity. Am J Trop Med Hyg 34(4): 714-720.

5. Da-Cruz AM, Filgueiras DV, Coutinho Z, Mayrink W, Grimaldi G, et al. (1999) Atypical mucocutaneous leishmaniasis caused by Leishmania braziliensis in an acquired immunodeficiency syndrome patient: T-cell responses and remission of lesions associated with antigen immunotherapy. Mem Inst Oswaldo Cruz 94(4): 537-542.

6. Sakaguchi S (2000) Regulatory T cell: key controllers of immunologic self-tolerance. Cell Mol Biol 101(5): 455-458.

7. Shevach EM (2002) CD4+ CD25+ suppressor T cells: more questions than answers. Nat Rev Immunol 2(6): 389-400.

8. Read S, Powrie F (2001) CD4+ regulatory T cells. Curr Opin Immunol. Cur Opin Immunol 13(6): 644-649.

9. Reed SG (2001) Leishmaniasis vaccination: targeting the source of infection. J Exp Med 194(3): 7-10.

10. McHugh RS, Whitters MJ, Piccirillo CA, Young DA, Shevach EM, et al. (2002) CD4(+) CD25(+) immunoregulatory T cells: gene expression analysis reveals a functional role for the glucocorticoid-induced TNF receptor. Immunity 16(2): 311-323.

11. Levings MK, Romina S, Roncarolo MG (2001) Human CD25(+) CD4(+) $\mathrm{T}$ regulatory cells suppress naive and memory $\mathrm{T}$ cell proliferation and can be expanded in vitro without loss of function. J Exp Med 193(11): 1295-1302.

12. Thormton AM, Shevach EM (1998) CD4+CD25+immunoregulatory $\mathrm{T}$ cells suppress polyclonal T-cell activation in vitro by inhibiting interleukin-2 production. J Exp Med 188(2): 287-296.

13. Baecher-Allan C, Brown JA, Freeman GJ, Hafler DA (2001) CD4+CD25+high regulatory cells in human peripheral blood. J Immunol 167(3): 1245-1253.

14. Dieckmann D, Plottner H, Berchtold S, Berger T, Schuler G (2001) Ex vivo isolation and characterization of CD4+CD25+ T cells with regulatory properties from human blood. J Exp Med 193(11): 1303-1310.

15. Jonuleit H, Schmitt E, Stassen M, Tuettenberg A, Knop J, et al. (2001) Identification and functional characterization of human CD4+CD25= T cells with regulatory properties isolated from peripheral blood. J Exp Med 193(11): 1285-1294.

16. Annunziato F, Cosmi L, Liotta F, Lazzeri E, Manetti R, et al. (2002) Phenotype, localization, and mechanism of suppression of CD4(+) CD25(+) human thymocytes. J Exp Med 196(3): 379-387.

17. Sakaguchi S, Sakaguchi N, Asano M, Itoh M, Toda M (1995) Immunologic self-tolerance maintained by activated $\mathrm{T}$ cells expressing IL-2 receptor alpha-chains (CD25). Breakdown of a single mechanism of self-tolerance causes various autoimmune diseases. J Immunol 155(3): 1151-1164.

18. Shevach EM (2002) CD4+ CD25+ suppressor T cells: more questions than answers. Nat Rev Immunol 2(6): 389-400.

19. Read S, Malmström V, Powrie F (2000) Cytotoxic T lymphocyteassociated antigen 4 plays an essential role in the function of CD25(+) CD4(+) regulatory cells that control intestinal inflammation. J Exp Med 192(2): 295-302.

20.Suri-Payer E, Cantor H (2001) Differential cytokine requirements for regulation of autoimmune gastritis and colitis by CD4(+) CD25(+) T cells. J Autoimmun 16(2): 115-123. 
21. Brunkow ME, Jeffery EW, Hjerrild KA, Paeper B, Clark LB, et al. (2001) Disruption of a new forkhead/winged-helix protein, Scurfin, results in the fatal lymphoproliferative disorder of the scurfy mouse. Nat Genet 27(1): 68-73

22. Gambineri E, Torgerson TR, Ochs HD (2003) Immune dysregulation, polyendocrinopathy, enteropathy, and X-linked inheritance (IPEX), a syndrome of systemic autoimmunity caused by mutations of FOXP3, a critical regulator of T-cell homeostasis. Curr Opin Rheumatol 15(4): 430-435.

23. Talal A Chatila, Frank Blaeser, Nga Ho, Howard M, Lederman, et al. (2000) JM2, encoding a fork head-related protein, is mutated in X-linked autoimmunity-allergic disregulation syndrome. J Clin Invest 106(12): R75-81.

24. Bennett CL, Misslitz A, Colledge L, Aebischer T, Blackburn CC (2001). Silent infection of bone marrow-derived dendritic cells by Leishmania mexicana amastigotes. Eur J Immunol 31(3): 876-883.

25. Wildin RS, Ramsdell F, Peake J, Faravelli F, Casanova JL, et al. (2001) $\mathrm{X}$-linked neonatal diabetes mellitus, enteropathy and endocrinopathy syndrome is the human equivalent of mouse scurfy. Nat Genet 27(1): 18-20.

26. Fontenot JD, Gavin MA, Rudensky AY (2003) Foxp3 programs the development and function of $\mathrm{CD} 4+\mathrm{CD} 25+$ regulatory $\mathrm{T}$ cells. Nat Immunol 4(4): 330-336.

27. Hori S, Takahashi T, Sakaguchi S (2003) Control of autoimmunity by naturally arising regulatory CD4+ T cells. Adv Immunol 81: 331-371.

28. Khattri R, Cox T, Yasayko SA, Ramsdell F (2003) An essential role for Scurfin in CD4+CD25+ T regulatory cells. Nat Immunol 4(4): 337-342.

29. Maloy KJ, Powrie F (2001) Regulatory Tcells in the control of immune pathology. Nat Immunol 2(9): 816-822.

30. Asseman C, von Herrath M (2002) About CD4pos CD25pos regulatory cells. Autoimmun Rev 1(4): 190-197.

31. Gavin MA, Clarke SR, Negrou E, Gallegos A, Rudensky A (2002) Homeostasis and anergy of $\mathrm{CD} 4(+) \mathrm{CD} 25(+)$ suppressor $\mathrm{T}$ cells in vivo. Nat Immunol 3(1): 33-41.

32. Aseffa A, Gumy A, Launois P, MacDonald HR, Louis JA, et al. (2002) The early IL-4 response to Leishmania major and the resulting Th2 cell maturation steering progressive disease in BALB/c mice are subject to the control of regulatory CD4+CD25+ T cells. J Immunol 169(6): 3232 3241.

33. Hori S, Haury M, Lafaille JJ, Demengeot J, Coutinho A (2002) Peripheral expansion of thymus-derived regulatory cells in anti-myelin basic protein T cell receptor transgenic mice. Eur J Immunol 32(12): 37293735 .

34. Suvas S, Kumaraguru U, Pack CD, Lee S, Rouse BT (2003) CD4+CD25+ T cells regulate virus-specific primary and memory CD8+ T cell responses. J Exp Med 198(6): 889-901.

\section{ISSN: 2574-1241}

\section{DOI: $10.26717 / B J S T R .2018 .10 .002008$}

Dayakar Alti. Biomed J Sci \& Tech Res

This work is licensed under Creative

Commons Attribution 4.0 License

Submission Link: https://biomedres.us/submit-manuscript.php
35.Xu D, Liu H, Komai-Koma M, Campbell C, McSharry C, et al. (2003) CD4+CD25+ regulatory $\mathrm{T}$ cells suppress differentiation and functions of Th1 and Th2 cells, Leishmania major infection, and colitis in mice. J Immunol 170(1): 394-399.

36. Belkaid Y, Piccirillo CA, Mendez S, Shevach EM, Sacks DL (2002) CD4+CD25+ regulatory $\mathrm{T}$ cells control Leishmania major persistence and immunity. Nature 420(6915): 502-507.

37. Méndez S, Belkaid Y, Seder RA, Sacks D (2002) Optimization of DNA vaccination against cutaneous leishmaniasis. Vaccine 20(31-32): 37023708.

38. Mendez S, Reckling SK, Piccirillo CA, Sacks D, Belkaid Y (2004) Role for $\mathrm{CD} 4(+) \mathrm{CD} 25(+)$ regulatory $\mathrm{T}$ cells in reactivation of persistent leishmaniasis and control of concomitant immunity. J Exp Med 200(2): 201-210.

39. Nylén S, Maurya R, Eidsmo L, Manandhar KD, Sundar S, et al. (2007) Splenic accumulation of IL-10 mRNA in T cells distinct from CD4+CD25+ (Foxp3) regulatory $\mathrm{T}$ cells in human visceral leishmaniasis. J Exp Med 204(4): 805-817.

40. K Kemp, M Kemp, A Kharazmi, A Ismail, JAL Kurtzhals, et al. (1999) Leishmania-specific T cells expressing interferon-gamma (IFN-gamma) and IL-10 upon activation are expanded in individuals cured of visceral leishmaniasis. Clin Exp Immunol 116(3): 500-504.

41. Anderson CF, Oukka M, Kuchroo VJ, Sacks D (2007) CD4+CD25-Foxp3Th1 cells are the source of IL 10-mediated immune suppression in chronic cutaneous leishmaniasis. J Exp Med 204(2): 285-297.

42. Müller I, Pedrazzini T, Farrell JP, Louis J (1989) T-cell responses and immunity to experimental infection with leishmania major. Annu Rev Immunol 7: 561-578.

43. Stobie L, Gurunathan S, Prussin C, Sacks DL, Glaichenhaus N, et al. (2000) The role of antigen and IL-12 in sustaining Th1 memory cells in vivo: IL-12 is required to maintain memory/effector Th1 cells sufficient to mediate protection to an infectious parasite challenge. Proc Natl Acad Sci USA 97(15): 8427-8432.

44. Karp CL, el-Safi SH, Wynn TA, Satti MM, Kordofani AM, et al. (1993) In vivo cytokine profiles in patients with kala-azar. Marked elevation of both interleukin-10 and interferon-gamma. J Clin Invest 91(4): 16441648.

45. Ghalib HW, Piuvezam MR, Skeiky YA, Siddig M, Hashim FA, et al. (1993) Interleukin 10 production correlates with pathology in human Leishmania donovani infections. J Clin Invest 92(1): 324-329.

46. Kenney RT, Sacks DL, Gam AA, Murray HW, Sundar S (1998). Splenic cytokine responses in Indian kala-azar before and after treatment. J Infect Dis 177(3): 815-818.

47. Faleiro RJ, Kumar R, Hafner LM, Engwerda CR (2014) Immune Regulation during Chronic Visceral Leishmaniasis. PLoS Negl Trop Dis 8(7): e2914.

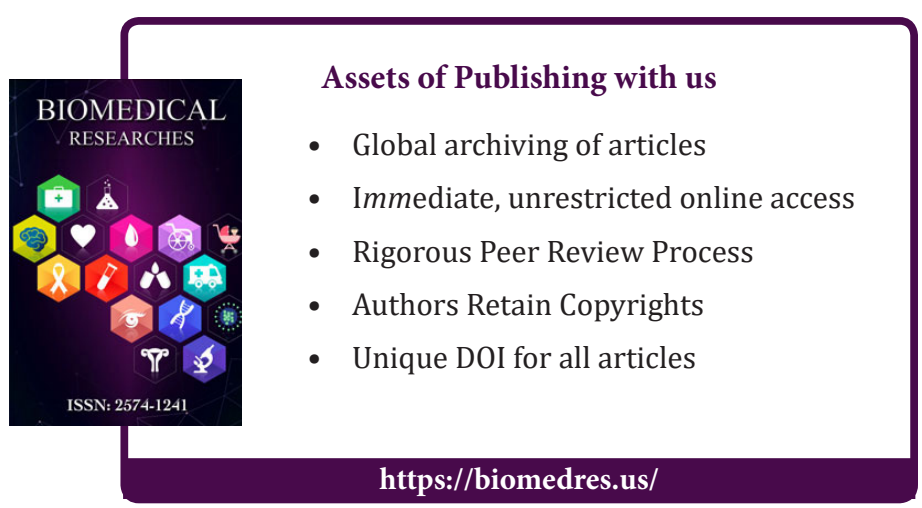

